\section{Three additional lizard (Squamata: Sauria) records for Mizoram, India}

\author{
H.T. Lalremsanga ${ }^{1}$, Lalmalsawma Khawlhring ${ }^{2}$ \\ \& Lalrotluanga ${ }^{3}$ \\ ${ }^{1,3}$ Department of Zoology, ${ }^{2}$ Department of Forestry, \\ Mizoram University, Aizawl, Mizoram 796012, India \\ Email: ${ }^{1}$ htlrsa@yahoo.co.in, ${ }^{3}$ mskholhring@gmail.com
}

Few herpetofaunal inventories have been conducted in Mizoram. Pawar \& Birand (2001) documented 22 species of lizards from Dampa Tiger Reserve, Ngengpui Wildlife Sanctuary and Palak Lake, in the state. Ramanujam \& Harit (2002) recorded eight species of lizards from Mizoram. Recently, the State Fauna Series by Zoological Survey of India, by Mathew (2007) enumerated 22 species of lizards from Mizoram. The species reported by earlier workers represented only five families, Agamidae, Gekkonidae, Lacertidae, Scincidae and Varanidae (Table 1). We collected three additional species - Calotes maria, Calotes mystaceus and Ophisaurus gracilis which were not recorded previously from Mizoram (Image 1). Ophisaurus gracilis (Family Anguidae) represents a new family for the state.

For each specimen, selected morphometric measurements were made to the nearest $0.01 \mathrm{~mm}$ with dial calipers (Mitutoyo ${ }^{\mathrm{TM}}$ series No. 505-671). Morphometric and meristic characters (Table 2) largely follow those of Zug et al. (2006). The specimens were preserved in $8 \%$ buffered formalin and catalogued as voucher specimens in the museum of Zoology Department, Mizoram University.

\section{Calotes maria Gray, 1845 (Image 2) Family: Agamidae}

The individual was sighted and collected at $1250 \mathrm{hr}$ on 27 March 2008, in the outskirt of Selam Village at a geographical location of $23^{\circ} 48^{\prime} 21.9^{\prime \prime} \mathrm{N} \& 93^{\circ} 17^{\prime} 42.3^{\prime \prime} \mathrm{E}, 1,583 \mathrm{~m}$, inside the

Date of publication (online): 26 February 2010

Date of publication (print): 26 February 2010

ISSN $0974-7907$ (online) | 0974-7893 (print)

Editor: Indraneil Das

Manuscript details:

Ms \# 02246

Received 26 June 2009

Final received 18 August 2009

Finally accepted 03 December 2009

Citation: Lalremsanga, H.T., L. Khawlhring \& Lalrotluanga (2010). Three additiona lizard (Squamata: Sauria) records for Mizoram, India. Journal of Threatened Taxa 2(2): 718-720.

Copyright: (C) H.T. Lalremsanga, Lalmalsawma Khawlhring \& Lalrotluanga 2010 Creative Commons Attribution 3.0 Unported License. JoTT allows unrestricted use of this article in any medium for non-profit purposes, reproduction and distribution by providing adequate credit to the authors and the source of publication.

Acknowledgements: Lalmalsawma Khawlhring thanks the Department of Biotechnology (DBT), New Delhi for Junior Research Fellowship (JRF) and Dr. Kalidas Upadhyaya, Principal Investigator, Department of Forestry, Mizoram University for support. We also thank Abhijit Das, Division of Herpetology, Aaranyak, Guwahati, Assam for help in identification. We thank Prof. G.C. Jagetia, HOD of Zoology, Mizoram University for laboratory facilities.

OPEN AGGESS | FREE DOWNLOAD
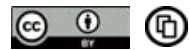

area of Lengteng Wildlife Sanctuary $\left(80 \mathrm{~km}^{2}\right)$, Champhai District, about $150 \mathrm{~km}$ to the northeast of Aizawl. While surveying the floral diversity of Lengteng Wildlife Sanctuary, the specimen was found on the roadside resting on the branch of Glochidion khasicum (Euphorbiaceae), at a height of $2 \mathrm{~m}$ from the ground. Photograph of this individual at the microhabitat is presented (Image 2). The forest type is subtropical semi-evergreen, corresponding to the sub-tropical hill forest (Champion \& Seth 1968) of Mizoram. The floral community of the collection site is dominated by the herb Ageratum adenophorum and patches of Maesa indica, and Eurya cerasifolia are also found. Trees of Quercus leucotrichophora, Lithocarpus dealbata, Schima wallichii, Lyonia ovalifolia and Vaccinium sprengelii also occur.

The specimen was kept in captivity alive for four days for behavioural studies. In the absence of sunlight, ventral side and flanks became light brown with the green colour persisting on the dorsum. In sunlight the whole body colour restored to bright green. In captivity, the individual preferred crickets though offered house-flies, moths and grasshoppers. The specimen was euthanized, preserved and catalogued as MZU/ ZOO/R-034 in the Museum of the Zoology Department, Mizoram University.

This record extends the range by ca. $240 \mathrm{~km}$, southeast from the Khasi Hills in Meghalaya, with the possibility of occurrence in the contiguous hill ranges.

\section{Calotes mystaceus Duméril \& Bibron, 1837 (Image 3) Family: Agamidae}

An individual Calotes mystaceus was observed perching on the branch of Pinus kesiya, about $3 \mathrm{~m}$ above the ground at the secondary forest area of Zotlang $\left(23^{\circ} 28^{\prime} 23.5^{\prime \prime} \mathrm{N} \&\right.$ 93019'59.2”E, 1,500m), Champhai Town, Champhai District on 26 May 2008 around $1600 \mathrm{hr}$. It was collected and kept for observation in captivity for two weeks in the departmental terrarium. The lizard remained greyish-brown colour inside the shaded terrarium, the head and anterior portion of the trunk turned to bright blue colour within five minutes after exposure to the sun. The animal was later preserved and catalogued as $\mathrm{MZU/ZOO/R-038.} \mathrm{Three} \mathrm{more} \mathrm{specimens,} \mathrm{MZU/ZOO/R-039,}$ $\mathrm{MZU/ZOO/R-040} \mathrm{and} \mathrm{MZU/ZOO/R-041} \mathrm{were} \mathrm{collected} \mathrm{from} \mathrm{the}$ same area during the month of February in 2009. Other agamids found in sympatry are Calotes jerdoni and Calotes versicolor.

\section{Ophisaurus gracilis Gray, 1845 (Image 4) Family: Anguidae}

While surveying the herpetofauna of Aizawl City, around 0730hr on 19 May 2008, a limbless lizard (MZU/ZOO/R-035) was seen basking in the sun inside the mixed plantation area of Brassica campestris, Acacia pennata, Trevesia palmata and Curcuma longa at Mualpui $\left(23^{\circ} 43.081^{\prime} \mathrm{N} \& 92^{\circ} 43.668^{\prime} \mathrm{E} ; 802 \mathrm{~m}\right)$, Aizawl where the atmospheric air temperature and relative humidity were $25^{\circ} \mathrm{C}$ and $74 \%$, respectively. We were informed that another specimen was killed the previous day by the local people the remains were salvaged from the leaf litter $10 \mathrm{~m}$ away from the spot of occurrence of the first sample. It was preserved and catalogued as MZU/ZOO/R-036. On 22 May 2008 another specimen (MZU/ZOO/R-037) was collected from the same locality. All of them were identified as Ophisaurus gracilis. The dorsal and ventral scale rows for each specimen were 16 and 10, respectively. The specimen MZU/ZOO/R-035 


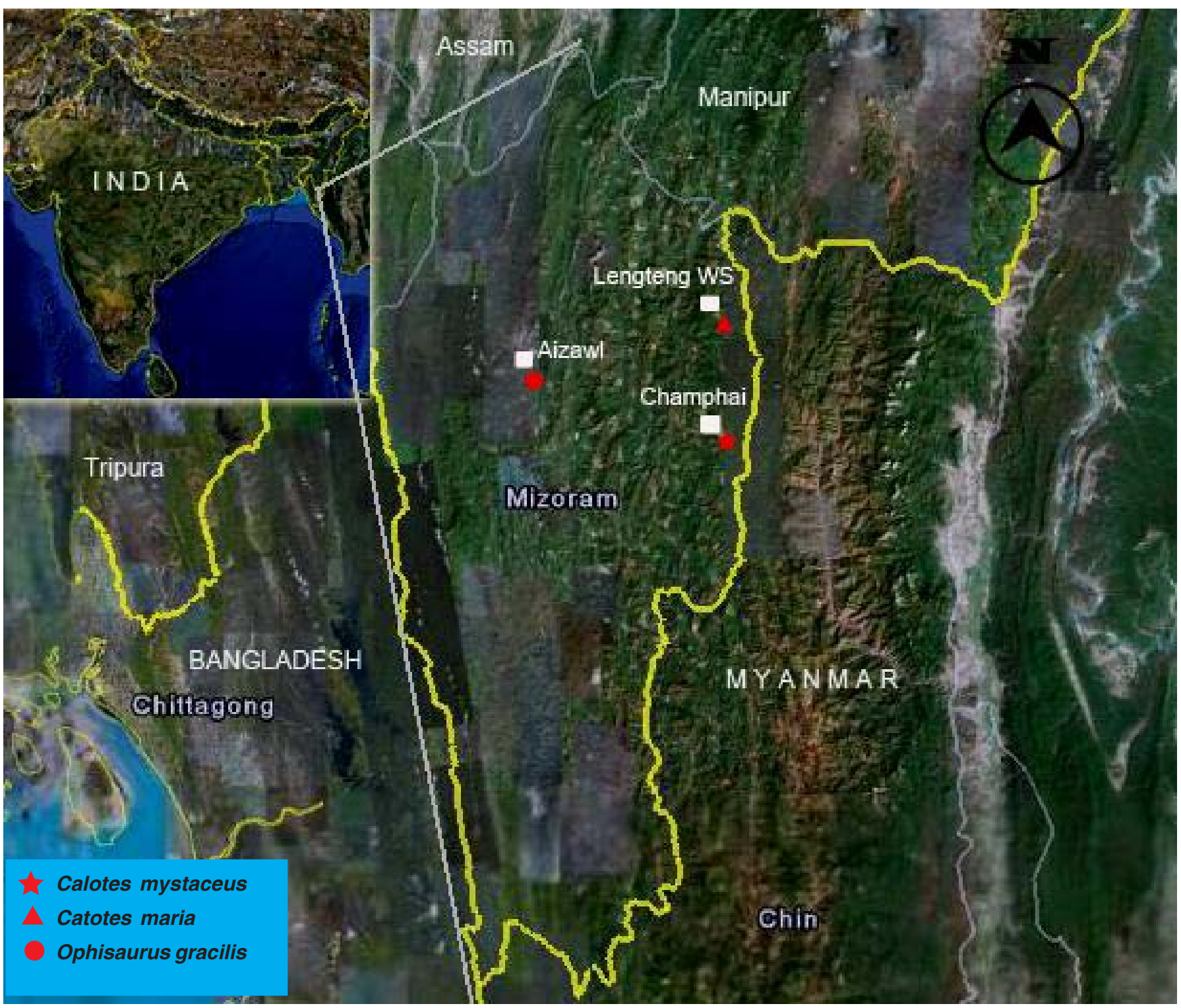

Image 1. Map of Mizoram showing the collection sites of Calotes maria, Calotes mystaceus and Ophisaurus gracilis

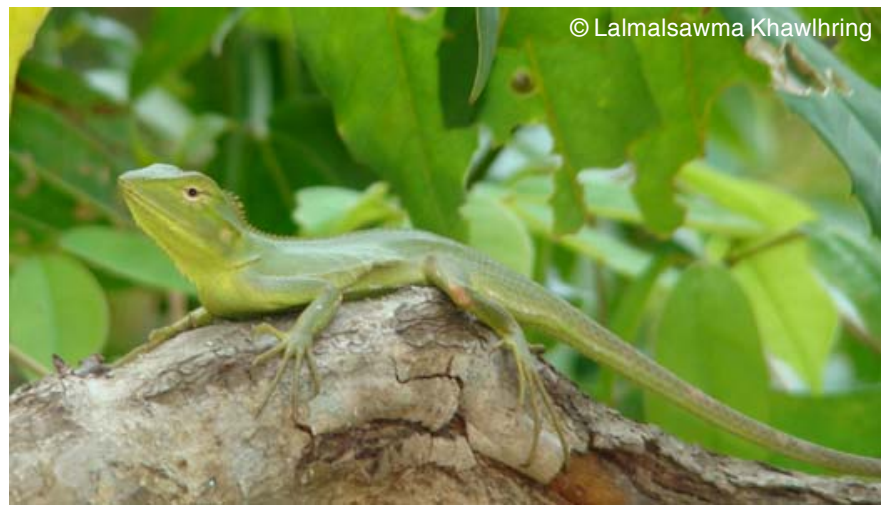

Image 2. Calotes maria

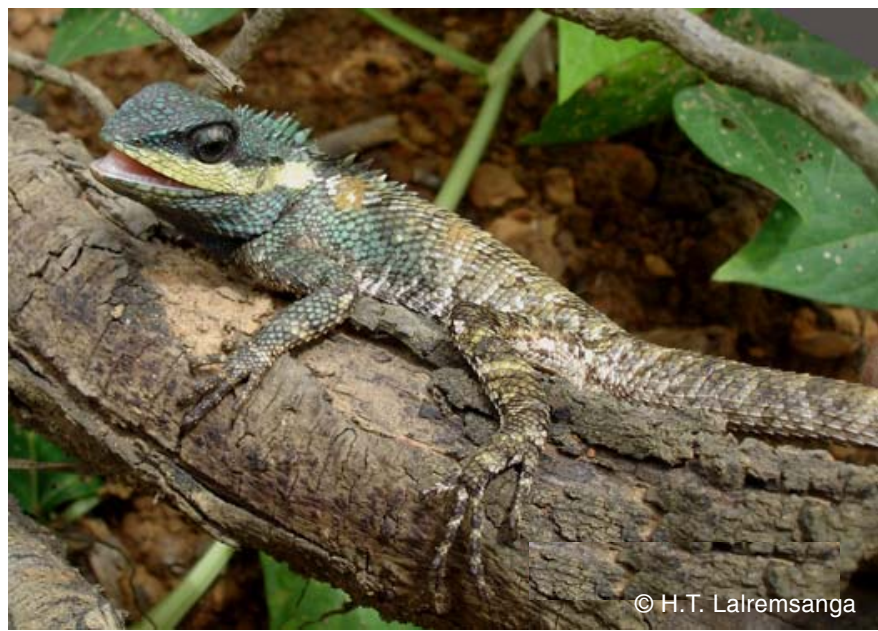

Image 3. Calotes mystaceus 
Table 1. Lizards species of Mizoram recorded by earlier workers

\begin{tabular}{|c|c|c|c|}
\hline Lizards & $\begin{array}{l}\text { Pawar \& } \\
\text { Birand } \\
(2001)\end{array}$ & $\begin{array}{l}\text { Harit \& } \\
\text { Ramanujam } \\
\text { (2002) }\end{array}$ & $\begin{array}{l}\text { Mathew } \\
\text { (2007) }\end{array}$ \\
\hline \multicolumn{4}{|l|}{ Agamidae } \\
\hline 1. Calotes cf. alticristatus & + & - & - \\
\hline 2. C. emma & + & - & + \\
\hline 3. C. jerdoni & + & - & + \\
\hline 4. C. versicolor & + & + & + \\
\hline 5. Draco maculatus & + & - & + \\
\hline 6. Draco sp. (cf. blanfordi-norvilli?) & + & - & - \\
\hline 7. Japalura planidorsata & + & - & - \\
\hline 8. J. variegata & - & - & + \\
\hline 9. Ptyctolaemus gularis & + & - & + \\
\hline \multicolumn{4}{|l|}{ Gekkonidae } \\
\hline 10. Cosymbotus platyurus & + & + & + \\
\hline 11. Cyrtodactylus khasiensis & + & - & + \\
\hline 12. Gekko gecko & + & + & + \\
\hline 13. Hemidactylus brooki & - & + & + \\
\hline 14. H. flaviviridis & - & + & - \\
\hline 15. $H$. frenatus & + & - & + \\
\hline 16. H. garnoti & + & - & + \\
\hline 17. Ptychozoon lionotum & + & - & - \\
\hline 18. P. horsfieldi & - & - & + \\
\hline \multicolumn{4}{|l|}{ Lacertidae } \\
\hline 19. Takydromus sexlineatus & + & - & + \\
\hline \multicolumn{4}{|l|}{ Scincidae } \\
\hline 20. Shenomorphus maculatus & + & - & + \\
\hline 21. S. courcyanum & + & - & - \\
\hline 22. S.indicum & + & - & + \\
\hline 23. Lygosoma punctata & - & + & + \\
\hline 24. Mabuya carinata & - & + & + \\
\hline 25. M. multifasciata & + & - & + \\
\hline 26. M. macularia macularia & + & - & + \\
\hline 27. Mabuya. sp. & + & - & - \\
\hline 28. Tropidophorus assamensis & - & - & + \\
\hline \multicolumn{4}{|l|}{ Varanidae } \\
\hline 29. Varanus bengalensis & + & + & + \\
\hline 30. V. salvator & + & - & - \\
\hline
\end{tabular}

+ = recorded; - = not recorded

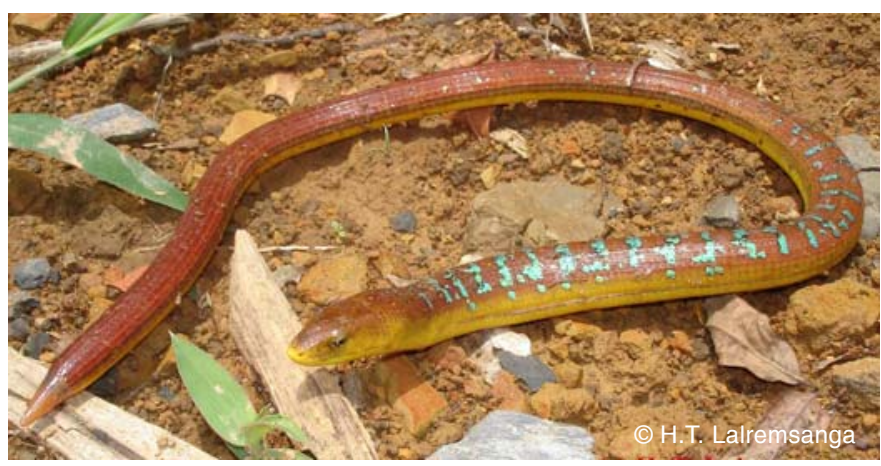

Image 4. Ophiosaurus gracilis

was kept in captivity for 64 days (19 May to 22 July 2008) to study behaviour and feeding habits. The saurian fauna of this area include Calotes versicolor, Cosymbotus platyurus, Eutropis macularia, Eutropis multifasciata, Gekko gecko, Hemidactylus frenatus, Hemidactylus garnoti, Ptyctolaemus gularis and Sphenomorphus maculatus.

\section{Discussion}

These records are of interest for extending their distribution southwards in northeastern India. It is noteworthy that none of these species are common lizards. Local sources informed that Calotes mystaceus is common in Champhai Town area, while Ophisaurus gracilis was seen occasionally and Calotes maria was rare.

\section{References}

Champion, H.G. \& S.K. Seth (1968). A Revised Survey of the Forest Types of India. Published by Govt. of India, New Delhi. xxvii+404pp.

Harit, D.N. \& S.N. Ramanujam (2002). Reptilian fauna of Mizoram, India. Cobra 47:5-7.

Matthew, R. (2007). Reptilia, pp. 545-577. In: the Director (eds.). Fauna of Mizoram, State Fauna Series, 14. Published by Zoological Survey of India, Kolkata, v+691pp.

Table 2. Mensural (in $\mathrm{mm}$ ) and meristic measurements of three new lizards for Mizoram

\begin{tabular}{|c|c|c|c|c|c|c|c|c|c|}
\hline & Species & Museum No. & SVL & TL & HL & HW & SNL & IOD & MSR \\
\hline 1. & Calotes maria & MZU/ZOO/R-034 & 80.70 & 287.63 & 19.50 & 15.64 & 10.85 & 9.45 & $53-55$ \\
\hline 2. & Ophisaurus gracilis & MZU/ZOO/R-035 & 183.61 & 242.25 & 18.53 & 12.94 & 6.50 & 6.80 & 26 \\
\hline 3. & O. gracilis & MZU/ZOO/R-036 & 206.0 & 103.14 & 19.68 & 15.24 & 7.50 & 7.82 & 26 \\
\hline 4. & O. gracilis & MZU/ZOO/R-037 & 183.57 & 117.25 & 18.56 & 14.08 & 7.0 & 7.30 & 26 \\
\hline 5. & Calotes mystaceus & MZU/ZOO/R-038 & 119.82 & 215.0 & 25.54 & 24.62 & 14.12 & 15.12 & $53-54$ \\
\hline 6. & C. mystaceus & MZU/ZOO/R-039 & 97.86 & 176.23 & 22.12 & 19.86 & 12.85 & 13.54 & $50-52$ \\
\hline 7. & C. mystaceus & $\mathrm{MZU} / \mathrm{ZOO} / \mathrm{R}-040$ & 101.24 & $86^{\star}$ & 21.62 & 19.0 & 12.50 & 12.64 & $51-54$ \\
\hline 8. & C. mystaceus & MZU/ZOO/R-041 & 138.60 & 199.53 & 29.38 & 25.44 & 13.80 & 14.18 & $49-53$ \\
\hline
\end{tabular}

SVL - Snout-vent length; TL - Tail length; HL - Head length; HW - Head width; SNL - Snout length; IOD - Interorbital distance; MSR - Midbody scale rows; * - Tail broken around mid-portion

Pawar, S. \& A. Birand (2001). A survey of amphibians, reptiles, and birds in Northeast India. CERC Technical Report \#6, Centre for Ecological Research and Conservation, Mysore, 118pp.

Zug, G.R., H.H.K. Brown, J.A. Schulte II \& J.V. Vindum (2006). A systematic of the garden lizards, Calotes versicolor group (Reptilia, Squamata, Agamidae), in Myanmar: Central dry zone populations. Proceedings of the California Academy of Sciences $4^{\text {th }}$ series 57(2): 35-68. 